\title{
The Impact of Advertising on Consumer Purchase Decision with Reference to Consumer Durable Goods in Oman
}

\author{
Amandeep $^{1}$, Dr. Seema Varshney ${ }^{2}$, Syed Aulia ${ }^{2}$ \\ ${ }^{1}$ MBA-Student, WCAS - Muscat Oman. \\ ${ }^{2}$ Asst. Professor, WCAS - Muscat Oman.
}

*Corresponding Author: Syed Aulia, Asst. Professor, WCAS - Muscat Oman

\begin{abstract}
In globalized world, advertising has a huge and important role in promoting the products and the services. With the rapid development in technology and influence of media advertising has become an inevitable part of promotion mix. Through advertisement both electronic and print more audience can be reached and can have more impact on them, advertisements can be used to inform the new audiences, persuade them to buy the product and it can have huge influence on consumer decision making, advertisement can also be used as reminder to the existing customer about their connectivity to their products and have long lasting association with product or services and helps in brand building creating brand loyalty. People are more often are influenced by advertisement especially with reference to consumer durables and the current study investigates the impact on how different advertising strategies can influence the consumer decision regarding purchasing of consumer durables in sultanate of Oman.
\end{abstract}

Keywords: Advertisement, Consumer Purchase decision, Consumer durable goods, Sultanate of Oman.

\section{INTRODUCTION \& LITERATURE REVIEW}

According to Philip Kotler advertising is defined as "Any paid form of non-personal presentation \& promotions of idea, goods, or services by an identified sponsor."(Kotler, 2013)

Advertising plays a vital role in shaping dreams and helping customers in taking conscious product and brand decisions. Through advertisement the impact can reach a wider audience, and the main motive of advertising is to inform/ persuade / convince / remind the customers about the product/services. Advertising among competing brands has seen to be rapidly increasing and has made consumers more knowledgeable about several products and services in the market. Advertising has evolved from the local stage to an international level. Now corporations are looking outside their own country for new customers. Most of the adverts use appealing images and persuasive words to convince individual's perception about the product. New ideas and innovative ways attract customers to buy the product and remember the brands. Advertisements have a major role in influencing customers' purchase intention. Advertisement with endorsements creates easy remembrance for the customer's for the advertised product. The customer often tends to associate the brand with the celebrity and can easily register the brand in their mind.

According to a research "Impact of Promotional Activities on Consumer Buying Behavior: A Study of Cosmetic Industry" that customer behavior study is based on the consumer buying behavior. The consumer plays three roles: role of user, payer and buyer. There is a positive relationship between Relevant News and pleasure, indicating that relevant news as a strong factor in inducing positive emotional responses.

According to a research on "Consumers' Perception on Online Shopping "(Dr.R.Shanthi, 2015)it's mostly the youngsters who are attached to online shopping whereas the senior people still prefer the traditional methods of buying the product in comparison with the young adults. However there is shift in focus where middle age people are showing inertest towards online shopping as well. This study also reveals that the price of the products has the most influencing factor on online purchase. 


\subsection{Problem Statement}

In the current world advertising plays an effective role in promotion of goods and services. Advertising serves as a key tool in creating product awareness in the mind of a potential consumer to take eventual purchase decision. This study focuses on The Impact of Advertising on Consumer Purchase Decision with reference to Consumer durable Goods in Oman (Muscat) this is a first research of its type as up to date there is no research the same.

\section{THEORETICAL CONCEPTS AND FRAMEWORK}

People have different liking and choice. This could be because of the varied experiences and backgrounds of individuals. Past experience of the person subjected to advertising may determine the impact the advertising will have on him or her. This preference is referred as consumer behavior.

According to Philip Kotler consumer purchase decisions are influenced by cultural, social psychological and personal characteristics. Measuring the influence of advertisement in consumer brand preference is very important for every marketer. If the advertisement doesn't create any positive impact on consumers' brand preference, all the resources such as money, time and efforts spent on advertisement will go in vain. Most advertising agency try to understand the desires of their target market in their approach to advertising. Often, advertising agencies through their advertisements look for building long lasting relationship with people. As a result, they find out ways to turn one-time purchasers into lifelong customers.

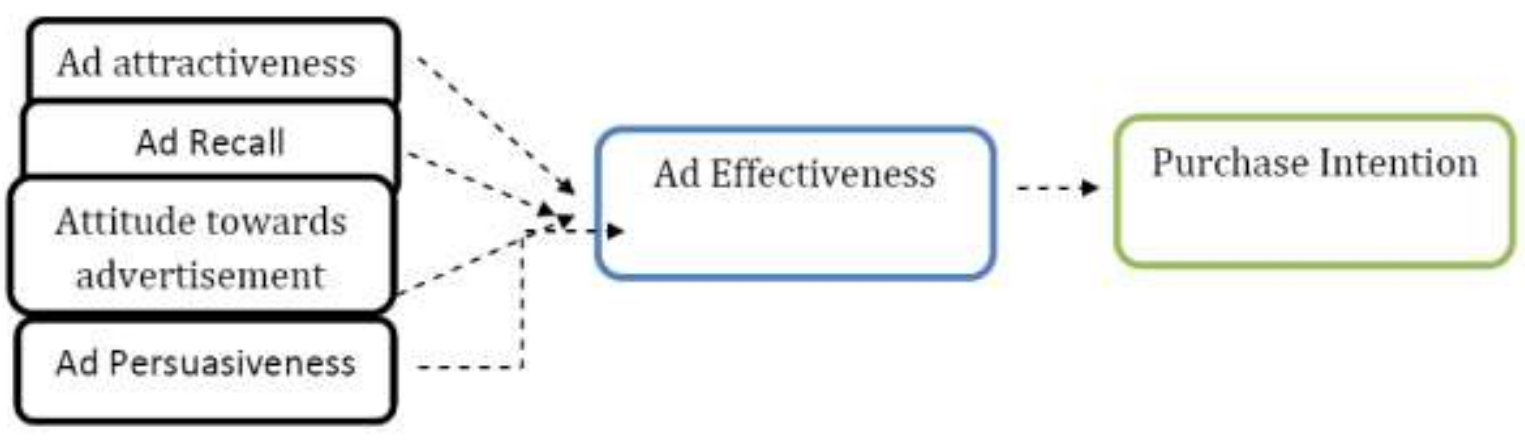

Figure1. A structural Model studying the factors affecting ad effectiveness

\subsection{Significance of Study}

The findings of this study would serve a benefit to the marketers in understanding The Impact of Advertising on Consumer Purchase Decision with reference to Consumer durable Goods in Oman and ways to increase their sales.

\subsection{Objectives of the Study}

To study the Impact of Advertising on Consumer Purchase Decision with reference to Consumer durable Goods in Oman.

To study various factors affecting the consumer buying process with respect to advertisements.

\section{Hypothesis}

H1: Attractive ads have no influence on purchase intension.

H2: Persuasive ads have no influence on purchase intension.

\subsection{Scope of the Study}

This study focuses on the understanding The Impact of Advertising on Consumer Purchase Decision with reference to Consumer Goods in Oman (Muscat), where there is mostly organized retail.

\section{RESEARCH METHODOLOGY}

Quantitative study was done to understand the Impact of Advertising on Consumer Purchase Decision with reference to Consumer durable Goods in Oman. Descriptive research design was used for the current research study using Non-probability - Convenience Sampling. Samples were selected on the 
The Impact of Advertising on Consumer Purchase Decision with Reference to Consumer Durable Goods in Oman

basis of accessibility of the samples. Sample Size was 100, it includes working men and women, housewives and students and sample unit comprises of individual customers.

Both primary and secondary information have been collected for the Purpose of Research. The research is based on Quantitative data analysis. Primary data required for the research, has been collected through questionnaires. Literature review is considered as secondary data for the research.

\subsection{Analysis of Data: Tools \& Techniques}

Data analyzed using different statistical tools Correlation and Regression analysis are used to study the relationship of different variables of advertising and their impact on purchase decision of an individual.

1. How frequently do you watch ads?

\begin{tabular}{|l|l|c|c|}
\hline \multicolumn{2}{|c|}{} & Frequency & Percent \\
\hline \multirow{4}{*}{ Valid } & Frequently & 44 & 41.5 \\
\cline { 2 - 4 } & Never & 2 & 1.9 \\
\cline { 2 - 4 } & Rarely & 28 & 26.4 \\
\cline { 2 - 4 } & Sometimes & 32 & 30.2 \\
\cline { 2 - 4 } & Total & 106 & 100.0 \\
\hline
\end{tabular}

Majority of the respondents that is $41.51 \%$ of them frequently watch ads. $30.19 \%$ of them watch ads only sometimes, $26.42 \%$ of them rarely watch ads. Around $1.89 \%$ of them never watch ads.

2. Recently which Product did you buy?

\begin{tabular}{|c|l|c|c|}
\hline \multicolumn{2}{|c|}{} & Frequency & Percent \\
\hline Valid & AC & 13 & 12.3 \\
\cline { 2 - 4 } & Any Other(Specify) & 3 & 2.8 \\
\cline { 2 - 4 } & Cooler & 1 & .9 \\
\cline { 2 - 4 } & DVD & 24 & 22.6 \\
\cline { 2 - 4 } & Microwave Owen & 1 & .9 \\
\cline { 2 - 4 } & Mobile & 2 & 1.9 \\
\cline { 2 - 4 } & Refrigerator & 21 & 19.8 \\
\cline { 2 - 4 } & RO & 1 & .9 \\
\cline { 2 - 4 } & TV & 37 & 34.9 \\
\cline { 2 - 4 } & washing machine & 1 & .9 \\
\cline { 2 - 4 } & WASHING MACHINE & 1 & .9 \\
\cline { 2 - 4 } & water dispenser & 1 & .9 \\
\cline { 2 - 4 } & Total & 106 & 100.0 \\
\hline
\end{tabular}

Recently majority of them $34.91 \%$ bought TV, $22.64 \%$ bought DVD, $19.81 \%$ bought Refrigerator, $12.26 \%$ bought $\mathrm{AC}$, and $1.89 \%$ bought mobile and a very small percentage that is $8.49 \%$ bought other items.

3. What influences you the most to try a new product or service?

\begin{tabular}{|l|l|c|c|}
\hline \multicolumn{2}{|c|}{} & Frequency & Percent \\
\hline \multirow{3}{*}{ Valid } & Advertisements & 35 & 33.0 \\
\cline { 2 - 4 } & expert advice & 19 & 17.9 \\
\cline { 2 - 4 } & personal experience & 21 & 19.8 \\
\cline { 2 - 4 } & $\begin{array}{l}\text { Recommendations from friends and } \\
\text { family }\end{array}$ & 19 & 17.9 \\
\cline { 2 - 4 } & Seeing famous people using & 12 & 11.3 \\
\cline { 2 - 4 } & Total & 106 & 100.0 \\
\hline
\end{tabular}

Majority of them $(33.02 \%)$ say that advertisements influence them the most to try new products, $19.81 \%$ say that personal experience influence them the most to try new products, $17.92 \%$ say that recommendations from friends and family and expert advice influence them the most to try new products and $11.32 \%$ try new products by seeing famous people using those products. 
The Impact of Advertising on Consumer Purchase Decision with Reference to Consumer Durable Goods in Oman

4. Reason behind the purchase of product goods?

\begin{tabular}{|c|l|c|c|}
\hline \multicolumn{1}{|c|}{} & Frequency & Percent \\
\hline Valid & Appealing Advertisement & 37 & 34.9 \\
\cline { 2 - 4 } & enhances the efficiency & 35 & 33.0 \\
\cline { 2 - 4 } & For satisfing my need & 1 & .9 \\
\cline { 2 - 4 } & functional benefit & 1 & .9 \\
\cline { 2 - 4 } & Increase in social status & 24 & 22.6 \\
\cline { 2 - 4 } & necessity & 1 & .9 \\
\cline { 2 - 4 } & Need & 1 & .9 \\
\cline { 2 - 4 } & Personal usage & 1 & .9 \\
\cline { 2 - 4 } & Traditional image & 5 & 4.7 \\
\cline { 2 - 4 } & Total & 106 & 100.0 \\
\hline
\end{tabular}

According to $34.91 \%$ appealing advertisements are the major reasons behind the purchase of durable goods, $33.02 \%$ agree that enhance in efficiency is the reason behind them buying the product, $22.64 \%$ say that the reason behind the purchase of products is the increase in social status, for $4.72 \%$ of them traditional image is the reason behind the purchase of products and $0.94 \%$ say there are other reason behind the purchase of products.

5. Factors influencing the purchase of durable goods

\begin{tabular}{|c|l|c|c|}
\hline \multicolumn{2}{|c|}{} & Frequency & Percent \\
\hline Valid & Company Advertising & 26 & 24.5 \\
\cline { 2 - 4 } & company reputation and price both & 1 & .9 \\
\cline { 2 - 4 } & Company Reputations & 34 & 32.1 \\
\cline { 2 - 4 } & Free Gift & 19 & 17.9 \\
\cline { 2 - 4 } & New feature introduced by company & 1 & .9 \\
\cline { 2 - 4 } & personal needs & 1 & .9 \\
\cline { 2 - 4 } & Price (use discount) & 24 & 22.6 \\
\cline { 2 - 4 } & Total & 106 & 100.0 \\
\hline
\end{tabular}

Majority of them that is $32.08 \%$ have said that Company's reputation influence then in purchase of the durable goods, for $24.53 \%$ of them Company's advertisement influence then in purchase of the durable goods, $22.64 \%$ of them purchase of the durable goods because the discounts offered, $17.92 \%$ of them purchase of the durable goods because free gifts, $0.94 \%$ purchase goods because of company's reputation and price both and a very small percentage that it $0.94 \%$ purchase goods for other reasons.

\subsection{Demographic profile of respondents}

\subsubsection{Age}

\begin{tabular}{|l|l|c|c|}
\hline \multicolumn{2}{|c|}{} & Frequency & Percent \\
\hline \multirow{4}{*}{ Valid } & $15-35$ & 58 & 54.7 \\
\cline { 2 - 4 } & $35-55$ & 35 & 33.0 \\
\cline { 2 - 4 } & 55 and above & 13 & 12.3 \\
\cline { 2 - 4 } & Total & 106 & 100.0 \\
\hline
\end{tabular}

Majority of the respondents that is $54.72 \%$ of them are in the age group between $15-35.33 .02 \%$ of the respondents are in the age group between 35-55 and the rest of the respondents that is $12.26 \%$ are in an age group of 55 and above.

\subsubsection{Gender}

\begin{tabular}{|c|c|c|c|}
\hline & & Frequency & Percent \\
\hline \multirow{3}{*}{ Valid } & Female & 53 & 50.0 \\
\hline & Male & 53 & 50.0 \\
\hline & Total & 106 & 100.0 \\
\hline
\end{tabular}

$50 \%$ of the respondents are females and $50 \%$ of them are males. 
The Impact of Advertising on Consumer Purchase Decision with Reference to Consumer Durable Goods in Oman

\subsubsection{Nationality}

\begin{tabular}{|c|l|c|c|}
\hline \multicolumn{2}{|c|}{} & Frequency & Percent \\
\hline \multirow{3}{*}{ Valid } & Non-Omani & 72 & 67.9 \\
\cline { 2 - 4 } & Omani & 34 & 32.1 \\
\cline { 2 - 4 } & Total & 106 & 100.0 \\
\hline
\end{tabular}

$67.92 \%$ of the respondents that is majority of them are Non-Omanis and the rest $32.08 \%$ of them were Omanis.

\subsubsection{Education Qualification}

\begin{tabular}{|c|l|c|c|}
\hline \multicolumn{2}{|c|}{ Valid } & Frequency & Percent \\
\cline { 2 - 4 } & Diploma & 23 & 21.7 \\
\cline { 2 - 4 } & Graduate & 42 & 39.6 \\
\cline { 2 - 4 } & Post-Graduate & 34 & 32.1 \\
\cline { 2 - 4 } & Schooling & 7 & 6.6 \\
\cline { 2 - 4 } & Total & 106 & 100.0 \\
\hline
\end{tabular}

$39.62 \%$ of the respondents are graduates, $32.08 \%$ of them are post -graduates, $21.07 \%$ of them are diploma students and $6.60 \%$ of them are school student.

\subsubsection{Occupation}

\begin{tabular}{|l|l|c|c|}
\hline \multicolumn{2}{|c|}{} & Frequency & Percent \\
\hline \multirow{4}{*}{ Valid } & Govt. services & 13 & 12.3 \\
\cline { 2 - 4 } & Homemaker & 14 & 13.2 \\
\cline { 2 - 4 } & Others & 6 & 5.7 \\
\cline { 2 - 4 } & Private services & 27 & 25.5 \\
\cline { 2 - 4 } & Self- employed & 6 & 5.7 \\
\cline { 2 - 4 } & Student & 40 & 37.7 \\
\cline { 2 - 4 } & Total & 106 & 100.0 \\
\hline
\end{tabular}

$37.74 \%$ of the respondents are students, $25.47 \%$ of them are in private services, $13.21 \%$ of are homemakers, $12.26 \%$ of them are in government service, $5.66 \%$ of them are in self employed and $5.66 \%$ of them in others.

\subsection{Reliability Statistics}

\subsubsection{Cronbach Alpha for Ad Attractiveness}

Cronbach alpha is used as a measure to access the internal consistency of a scale. As a rule of thumb if Cronbach alpha value is equal or more than 0.7 , internal consistency is said to be excellent and if it is less than 0.5 , it is not acceptable. The reliability of the above statement was tested by using Cronbach's Alpha value. It was found to be .875

\begin{tabular}{|c|c|c|c|c|}
\hline \multicolumn{5}{|c|}{ Correlations } \\
\hline \multicolumn{2}{|c|}{$\underline{\text { Correlation for Ad attractiveness }}$} & $\begin{array}{c}\text { While } \\
\text { watching the } \\
\text { ad I found it } \\
\text { attractive. }\end{array}$ & $\begin{array}{c}\text { The } \\
\text { commercial } \\
\text { was unique. }\end{array}$ & $\begin{array}{l}\text { I found the ad } \\
\text { appealing to me. }\end{array}$ \\
\hline \multirow{3}{*}{$\begin{array}{l}\text { While watching the ad I } \\
\text { found it attractive. }\end{array}$} & Pearson Correlation & 1 & $.628^{* *}$ & $.574^{* *}$ \\
\hline & Sig. (2-tailed) & & .000 & .000 \\
\hline & $\mathrm{N}$ & 106 & 106 & 106 \\
\hline \multirow{3}{*}{$\begin{array}{l}\text { The commercial was } \\
\text { unique. }\end{array}$} & Pearson Correlation & $.628^{* *}$ & 1 & $.563^{* * *}$ \\
\hline & Sig. (2-tailed) & .000 & & .000 \\
\hline & $\mathrm{N}$ & 106 & 106 & 106 \\
\hline \multirow{3}{*}{$\begin{array}{l}\text { I found the ad appealing } \\
\text { to me. }\end{array}$} & Pearson Correlation & $.574^{* * *}$ & $.563^{* * *}$ & 1 \\
\hline & Sig. (2-tailed) & .000 & .000 & \\
\hline & $\mathrm{N}$ & 106 & 106 & 106 \\
\hline \multirow[t]{3}{*}{ The ad was informative. } & Pearson Correlation & $.470^{* *}$ & $.480^{* * *}$ & $.631^{* * *}$ \\
\hline & Sig. (2-tailed) & .000 & .000 & .000 \\
\hline & $\mathrm{N}$ & 106 & 106 & 106 \\
\hline The ad was clear. & Pearson Correlation & $.418^{* *}$ & $.561^{* * *}$ & $.605^{* *}$ \\
\hline
\end{tabular}


The Impact of Advertising on Consumer Purchase Decision with Reference to Consumer Durable Goods in Oman

\begin{tabular}{|l|l|l|l|l|}
\hline \multirow{4}{*}{} & Sig. (2-tailed) & .000 & .000 & .000 \\
\cline { 2 - 5 } & $\mathrm{N}$ & 106 & 106 & 106 \\
\hline \multirow{2}{*}{\begin{tabular}{l} 
I would purchase the $\begin{array}{l}\text { product for which the } \\
\text { ad is shown. }\end{array}$ \\
\cline { 2 - 5 }
\end{tabular}} & Pearson Correlation & $.565^{* *}$ & $.474^{* *}$ & $.673^{* *}$ \\
\cline { 2 - 5 } & Sig. (2-tailed) & .000 & .000 & .000 \\
\cline { 2 - 5 } & $\mathrm{N}$ & 106 & 106 & 106 \\
\hline
\end{tabular}

\section{Analysis}

- Correlation between unique ad and Ad Attractiveness is significant (.628) at 0.01 level.

- Correlation between appealing ad and Ad Attractiveness is significant (.574) at 0.01 level.

- Correlation between informative ad and appealing ad is significant (.631) at 0.01 level.

- Correlation between clear ad and appealing ad is significant (.605) at 0.01 level.

- Correlation between purchase intension and appealing adis significant (.673) at 0.01 level.

- Correlation between attractive ad and purchase intension is significant (.565) at 0.01 level.

\subsection{Regression}

\begin{tabular}{|c|c|c|c|c|}
\hline \multicolumn{5}{|l|}{ Model Summary } \\
\hline Model & R & R Square & Adjusted R Square & Std. Error of the Estimate \\
\hline 1 & $.840^{\mathrm{a}}$ & .706 & .682 & .613 \\
\hline
\end{tabular}

a. Predictors: (Constant),

15) The ad changed my mind about the brand,

11) The ad was informative,

7)The commercial was unique,

14) The ad was persuasive,

6) While watching the ad I found it attractive,

12) The ad was clear,

10) I found the ad appealing to me,

8) I could relate to the characters in the advertisement.

Table tells us what \% of variability in the Dependant Variable is accounted for all of the Independent Variables.

\begin{tabular}{|c|l|c|c|c|c|c|}
\hline \multicolumn{2}{|c|}{ ANOVA $^{\text {a }}$} \\
\hline \multicolumn{2}{|c|}{ Model } & Sum of Squares & df & Mean Square & F & Sig. \\
\hline \multirow{3}{*}{1} & Regression & 87.428 & 8 & 10.928 & 29.098 & $.000^{\mathrm{b}}$ \\
\cline { 2 - 7 } & Residual & 36.431 & 97 & .376 & & \\
\cline { 2 - 8 } & Total & 123.858 & 105 & & & \\
\hline
\end{tabular}

a. Dependent Variable:

18) I would purchase the product for which the ad is shown.

b. Predictors: (Constant),

15) The ad changed my mind about the brand.,

11) The ad was informative.,

7) The commercial was unique.,

14) The ad was persuasive.,

6) While watching the ad I found it attractive.,

12) The ad was clear.,

10) I found the ad appealing to me.,

8) I could relate to the characters in the advertisement. 
The Impact of Advertising on Consumer Purchase Decision with Reference to Consumer Durable Goods in Oman

\begin{tabular}{|c|c|c|c|c|c|c|}
\hline \multicolumn{7}{|c|}{ Coefficients $^{\mathrm{a}}$} \\
\hline \multirow{2}{*}{\multicolumn{2}{|c|}{ Model }} & \multicolumn{2}{|c|}{$\begin{array}{l}\text { Unstandardized } \\
\text { Coefficients }\end{array}$} & \multirow{2}{*}{$\begin{array}{c}\begin{array}{c}\text { Standardized } \\
\text { Coefficients }\end{array} \\
\text { Beta }\end{array}$} & \multirow[t]{2}{*}{$\mathbf{t}$} & \multirow[t]{2}{*}{ Sig. } \\
\hline & & B & Std. Error & & & \\
\hline \multirow[t]{9}{*}{1} & (Constant) & .495 & .407 & & 1.218 & .226 \\
\hline & $\begin{array}{l}\text { While watching the ad I } \\
\text { found it attractive. }\end{array}$ & -.047 & .117 & -.033 & -.399 & .690 \\
\hline & $\begin{array}{l}\text { The commercial was } \\
\text { unique. }\end{array}$ & -.047 & .106 & -.037 & -.446 & .657 \\
\hline & $\begin{array}{l}\text { I could relate to the } \\
\text { characters in the } \\
\text { advertisement. }\end{array}$ & .086 & .093 & .086 & .923 & .359 \\
\hline & $\begin{array}{l}\text { I found the ad appealing } \\
\text { to me. }\end{array}$ & .141 & .099 & .130 & 1.425 & .157 \\
\hline & The ad was informative. & .089 & .115 & .064 & .773 & .441 \\
\hline & The ad was clear. & -.136 & .119 & -.099 & -1.150 & .253 \\
\hline & The ad was persuasive. & .244 & .090 & .224 & 2.701 & .008 \\
\hline & $\begin{array}{l}\text { The ad changed my mind } \\
\text { about the brand. }\end{array}$ & .553 & .096 & .566 & 5.747 & .000 \\
\hline
\end{tabular}

a. Dependent Variable:

18) I would purchase the product for which the ad is shown.

Based on this, below is the equation for the regression line:

Intention $=.495-.047($ attractive $)-.047($ unique $)+.086($ characters $)+.141($ appealing $)+.086($ informative $)-$ $.136($ clear $)+.244($ persuasive $)+.533($ brand $)$

According to Regression Analysis I would purchase the product for which the ad is shown because the ad is attractive, I could relate to the characters in the advertisement, ad is appealing, ad is informative and persuasive and changes by mind about the product.

\section{DISCUSSION ON FINDINGS OF THE STUDY}

The final sample size comprised of 100 respondents. Majority of the respondents that is $41.51 \%$ of them frequently watch advertisements and a very small percent that is around $1.89 \%$ of them never watch ads.

Majority of them $34.91 \%$ bought TV, $22.64 \%$ bought DVD, $19.81 \%$ bought Refrigerator, $12.26 \%$ bought $\mathrm{AC}$, and $1.89 \%$ bought mobile and a very small percentage that is $8.49 \%$ bought other items.

Majority of them (33.02\%) say that advertisements influence them the most to try new products. Majority of them that it around $34.91 \%$ say that appealing advertisements are the major reasons behind the purchase of durable goods. Majority of them that is $32.08 \%$ have said that Company's reputation influence then in purchase of the durable goods, for $24.53 \%$ of them Company's advertisement influence then in purchase of the durable goods, $22.64 \%$ of them purchase of the durable goods because the discounts offered, $17.92 \%$ of them purchase of the durable goods because free gifts, $0.94 \%$ purchase goods because of company's reputation and price both and a very small percentage that it $0.94 \%$ purchase goods for other reasons.

Majority of the respondents were in the age group 15-35 (54.72\%) 33.02\% of respondent are in the age group between $35-55$ and the rest of the respondents that is $12.26 \%$ are in an age group of 55 and above.

There are exact number of respondents $50 \%$ females and $50 \%$ of them are males.

Majority of the respondents were Non-Omanis $(67.92 \%)$ and the rest $32.08 \%$ of them were Omanis.

Majority of the respondents were graduates $39.62 \% .37 .74 \%$ of the respondents are students, $25.47 \%$ of them are in private services, $13.21 \%$ of are homemakers, $12.26 \%$ of them are in government service, $5.66 \%$ of them are in self employed and $5.66 \%$ of them in others. 
Correlation for Ad attractiveness Correlation between unique ad and Ad Attractiveness is significant (.628) at 0.01 level. Correlation for Ad attractiveness Correlation between appealing ad and $\mathrm{Ad}$ Attractiveness is significant (.574) at 0.01 level. Correlation for Ad attractiveness Correlation between unique ad and ad attractiveness Ad is significant (.628) at 0.01 level. Correlation for Ad attractiveness Correlation between appealing Ad and ad attractiveness is significant (.574) at 0.01 level. Correlation between ad persuasiveness and changed mind about the brand is significant (.705) at 0.01 level. Correlation between Ad persuasiveness and purchase intension is significant (.686) at 0.01 level.

\section{Testing of Hypothesis}

H1: Is false because as per Correlation between attractive ad and purchase intension is significant (.565) at 0.01 level.

H2: Is false because as per Correlation between purchase intension and ad persuasiveness is significant (.686) at 0.01 level.

\section{CONCLuSions}

This study aimed at understanding the Impact of Advertising on Consumer Purchase Decision with reference to Consumer durable Goods in Oman. Ad attractiveness, Adrecall, Attitude towards floor ads, Ad persuasiveness, and purchase intension are the different factors making up advertisements effectiveness. And it has been observed that they make a significant contribution to Ad effectiveness.

From the findings of this, we can interpret that there are four factors Ad recall, Ad persuasiveness, attitude towards $\mathrm{Ad}$ and $\mathrm{Ad}$ attractiveness all these factors contribute significantly to $\mathrm{Ad}$ effectiveness, and Ad persuasiveness has a largest contribution to Ad effectiveness and on the other hand Ad persuasiveness and Ad Attractiveness contribute heavily to purchase intention.

\subsection{Suggestions}

Based on the conceptual framework developed to study the impact of Advertising on Consumer Purchase Decision with reference to Consumer durable Goods in Oman, this paper tries to study certain constructs like Ad recall, Ad persuasiveness, attitude towards Ads, Ad attractiveness and purchase intention. Undoubtedly, Ad recall, Ad persuasiveness, attitude towards ads, Ad attractiveness, and purchase intension are the different factors making up Ad effectiveness with reference to the data in literature review.

\section{DiRECTIONS FOR FUTURE RESEARCH}

This research focuses on The Impact of Advertising on Consumer Purchase Decision with reference to Consumer durable Goods in Oman the same research can also be done take into account country in the other part of the world. Moreover, this research can be taken further by exploring some other factors that contribute to ad effectiveness; this would definitely provide a deeper insight into completely new dimensions that would help in improving the ads in order to attract more customers.

\section{REFERENCES}

[1] Chand, S. (n.d.). Consumer Behaviour: Meaning/Definition and Nature of Consumer Behaviour. Retrieved from Your article library: http://www.yourarticlelibrary.com/marketing/market-segmentation/consumerbehaviour-meaningdefinition-and-nature-of-consumer-behaviour/32301/

[2] Dr.R.Shanthi. (2015). Consumers' Perception on Online Shopping . Journal of Marketing and Consumer Research ISSN 2422-8451 An International Peer-reviewed Journal Vol.13, 2015.

[3] Hajli, M. N. (n.d.). A study of the impact of social media on consumers. International Journal of market Research Vol 56 Issue 3 .

[4] Hassan, A. (2015). Effects of TV Advertisement on Consumer Buying Behaviour: A Comparative Study of Rural-Urban and Male-Female Consumers. International Journal of Innovation and Applied Studies ISSN 2028-9324 Vol. 11 No. 3 Jun. 2015, pp. 608-614 .

[5] Hyun, S. S. (2011). The impact of advertising on patrons' emotional responses, perceived value, and behavioral intentions in the chain restaurant industry: The moderating role of advertising-induced arousal. International Journal of Hospitality Management . 
The Impact of Advertising on Consumer Purchase Decision with Reference to Consumer Durable Goods in Oman

[6] Principles of Marketing (2013). In P. Kotler. Dorling kindersley pvt ltd.

[7] Mandan, M. (2013). Investigating the Impact of Advertising on Customers' Behavioral Intentions A Case of Agriculture Bank. Macrothink Institute - Business and Economic Research ISSN 2162-4860 2013, Vol. 3, No. 1 .

[8] Shallu, M. (2013). Impact of Promotional Activities on Consumer Buying Behavior: A Study of Cosmetic Industry". IRACST - International Journal of Commerce, Business and Management (IJCBM) .

Citation: Amandeep, et al "The Impact of Advertising on Consumer Purchase Decision with Reference to Consumer Durable Goods in Oman" International Journal of Managerial Studies and Research (IJMSR), vol 5, no. 12, 2017, pp. 11-19. doi:http://dx.doi.org/10.20431/2349-0349.0512002.

Copyright: () 2017 Authors. This is an open-access article distributed under the terms of the Creative Commons Attribution License, which permits unrestricted use, distribution, and reproduction in any medium, provided the original author and source are credited. 